Article

\title{
Addressing Climate Change at the State and Local Level: Using Land Use Controls to Reduce Automobile Emissions
}

\author{
Rachel Medina and A. Dan Tarlock* \\ Chicago-Kent College of Law, Illinois Institute of Technology, 565 West Adams Street, Chicago, \\ IL 60661-3691, USA; E-Mail: rmedinaesq@gmail.com \\ * Author to whom correspondence should be addressed; E-Mail: dtarlock@kentlaw.edu; \\ Tel.: +1-312-906-5217; Fax: +1-312-906-5280.
}

Received: 29 April 2010; in revised form: 13 May 2010 / Accepted: 17 May 2010 /

Published: 18 June 2010

\begin{abstract}
Automobiles are a major source of $\mathrm{CO}_{2}$ emissions. Because there is no immediate technological fix to reduce these emissions, the most promising current strategy is to promote less automobile use. In the United States, this is difficult because federal programs such as the interstate highway system and local land use planning and regulation have encouraged suburban sprawl. In 2006, the state of California passed legislation to roll back greenhouse emissions to 1990 levels by 2020. This legislation did not link the roll back target with land use policies. However, NGOs and the state Attorney General used the state's pre-existing environmental impact assessment act to sue a large county east of Los Angeles alleging that its revised land use plan was inconsistent with the 2006 legislation. The state and the county settled the suit after the county agreed to new greenhouse gas mitigation duties, and in 2008 California passed additional legislation to implement its 2006 statute. Communities are strongly encouraged to adopt compact, transit-oriented development strategies to limit automobile use. The new legislation gives the attorney general and NGOs additional legal authority to challenge local land use plans and regulatory decisions which fail to adopt these strategies. California's important experiment has lessons for all urban areas struggling to reduce automobile $\mathrm{CO}_{2}$ emissions. It suggests that local land use controls can be added to the list of workable greenhouse gas mitigation strategies.
\end{abstract}

Keywords: sustainable land use; transportation-linked greenhouse gas reduction; environmental impact assessment; climate change 


\section{Introduction: The Necessity for Sub-Federal Action}

Sustainable development is widely accepted as an imperative policy objective to address the full range of environmental stresses to which the planet is subjected [1-3]. However, its meaning remains contested. The concept is open-ended and therefore does not fit neatly within the categories of either hard or soft law. In this paper we adopt a simple, functional definition of sustainable development and provide an example of an ambitious effort to apply it to Global Climate Change (GCC). Sustainable development functions as a target objective to which both public institutions and the market should be moving rather than a uniform end-state.

Scholars have amply documented the multiple ways in which society has encouraged unsustainable development. This paper provides a counter-example of the use of state legislation, supported by an aggressive judiciary and elected officials to implement and enforce the emerging international environmental norm that at least developed nations have a duty to reduce greenhouse gas emissions. The settlement of litigation in the largest county in the United States, located in the state of California, and subsequent state legislation, illustrate how domestic litigation can be used to strengthen the implementation of an aspirational, prior legislative duty to reduce greenhouse gas emissions. Non-governmental organizations and the California Attorney General creatively used the state's environmental impact legislation to force local governments to adopt land-use plans and regulations consistent with the state's ambitious GCC mitigation legislation, enacted with no clear implementation strategy. The state legislature subsequently enacted legislation that imposes new duties on local governments to develop land-use policies that reduce automobile use.

Any legal effort to force an emitter or contributor to greenhouse gas emissions to reduce these emissions is a challenge in the United States. As of early 2010, the federal government has no comprehensive climate change mitigation strategy [4]. The country never ratified the Kyoto Protocol and took the position that it would not act until both developed and developing nations agreed to reducing greenhouse gas emissions. More generally, the international community, partly but not exclusively because the lack of United States leadership, has been unable to agree on a mitigation regime consistent with the recommendations of the Intergovernmental Panel on Climate Change.

During the Administration of George W. Bush (2001-2009), federal GCC policy was limited to the sponsorship of research and the advocacy of voluntary reductions on the theory that the science of climate change was too uncertain to support national and international mandatory mitigation. However, as a scientific and popular consensus emerged that GCC demanded immediate action, states and local governments began to act to fill the vacuum created by federal inaction. The election of Barack Obama in 2008 led to the reversal of two key policies of the Bush Administration-the need for more research to reduce scientific uncertainty and the stress on voluntary reductions. However, the legislation pending in the United States Congress stresses offsets over net greenhouse gas reductions from major emitters [5]. Thus, supplemental actions will be necessary to meet any credible roll-back scenario.

The automobile loving U.S. state of California has been a leader in air pollution control because it generates so much pollution. Starting in the 1950s, it has had to address the smog in the Los Angeles basin, and it has been a leader in forcing the reduction of automobile pollution. This tradition was extended to GCC mitigation. In 2006, the legislature enacted the California Global Warming Solutions Act of 2006 (AB32) [6]. AB32 requires the California Air Resources Board to determine the statewide 
greenhouse gas emissions level in 1990 and to reduce the state's emissions to the 1990 baseline by 2020 [7]. The Board must adopt regulations that will require the reporting and verification of statewide greenhouse gas emissions and to monitor and enforce compliance with the reporting program [8].

\section{2. $\mathrm{CO}_{2}$ Emissions, the Automobile and Land-Use Patterns}

Greenhouse gas emissions come from many sources, but $\mathrm{CO}_{2}$ emissions from transportation are a major source of total emissions. According to the federal Environmental Protection Agency, $\mathrm{CO}_{2}$ emissions increased by 18 per cent from 1990 to 2008 ([9], ES-7). These emissions represent over 80 per cent of the greenhouse gas emissions in the United States ([9], ES-15). Ninety-four per cent of all $\mathrm{CO}_{2}$ emissions within the United States were from fossil fuel combustion ([9], ES-6). As Figure 1 demonstrates, the emissions come from the following sectors: electricity generation, transportation, industrial, residential, commercial, and U.S. Territories. Transportation accounted for the second largest percentage (32 per cent) of $\mathrm{CO}_{2}$ emissions within the United States in 2008, nearly 53 per cent of which is attributable to gasoline consumption for personal vehicle use ([9], ES-8). And, the anthropogenic sources of all transportation-related greenhouse gas emissions account for 27 per cent of total greenhouse gas emissions ([9], ES-14).

Figure 1. Percentage of $\mathrm{EO}_{2}$ Emissions from Fossil Fuel Combustion.

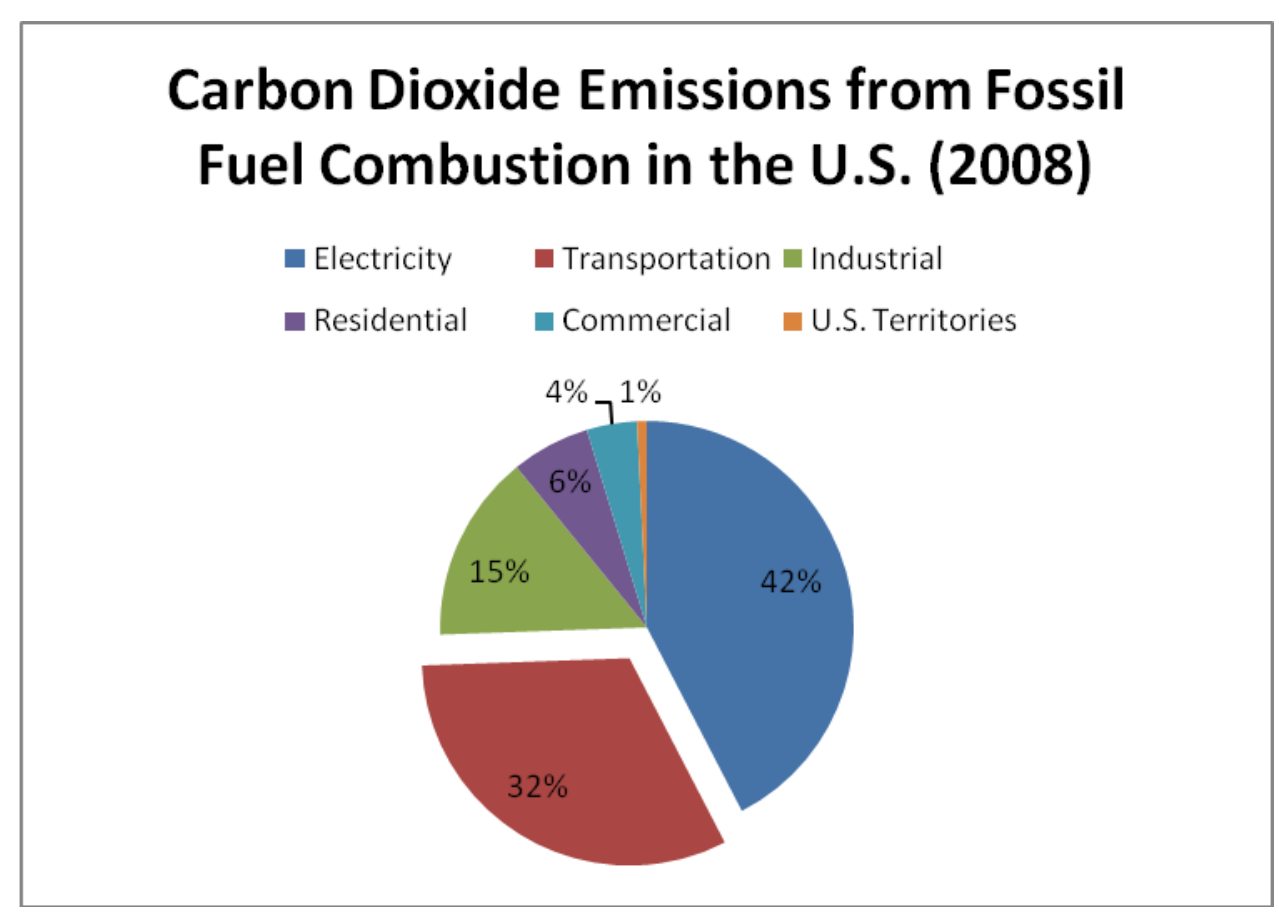

Unlike other automobile pollutants, there is no current technology to reduce greenhouse gases through modifications of the internal combustion engine. The only way to reduce them is to induce people to drive less, to switch the transportation of goods from highways to rail and water ways and to mandate more fuel efficient vehicles. At the current time, any form of tax on carbon emissions or other measures to force people to drive less are off the GCC mitigation agenda. 
Transportation emissions are in large part a function of where people live and where they work, shop and spend their leisure time. Thus, to address the reduction of automobile $\mathrm{CO}_{2}$ emissions, one must address the low-density urban settlement patterns which prevail in most of the United States and make people automobile-dependent for work, shopping and leisure. High-density land-use patterns with access to public transportation must be substituted for the current urban form. Current emissions levels are the result of federal, state and local land-use policies. United States land-use law encourages cities not to constrain residential and commercial land-use choices but to expand the range of these choices by favoring low density, suburban urbanization characterized by economic, racial and social segregation. United States land-use law has been limited to the segregation of uses by type primarily to prevent nuisance or external costs. Suburbanization has been encouraged by a variety of federal and state laws [10,11]. American cities are creatures of state legislatures and, with limited exceptions, states have rejected municipal ownership of raw land, land banking, the taxation of property left undeveloped, and the national provision of basic services such as education that European nations have used to promote relative urban compactness [12,13].

\subsection{Why and How the United States Institutionalized Automobile Dependence through Sprawl}

Addressing the reduction of $\mathrm{CO}_{2}$ transportation emissions runs against the grain of the deeply held American values of freedom of movement and choice of residence and the belief that climate should never be a barrier to settlement. And, these values are deeply embedded in United States land-use law. The culture of suburbanization or even more widely dispersed urban development is deeply ingrained in the American mind. Suburbanization began before the Civil War as the wealthy moved from crowded, unplanned, and unhealthy cities, but after World War II, affordable automobiles and federal mortgage polices enabled middle class families to flee cities en masse to escape the black migration from the rural south. Eventually, many cities became a way station between university and family for the young and the permanent province of the very rich, the very poor, and marginalized groups such as gay men and lesbians [14]. Planners, influenced by models of denser European settlement, have long tried to rein in endless suburbanization. Intellectuals supported these efforts by propounding the wasteland theory of suburbia. Economists have tried to help this project along by quantifying the external costs of sprawl [15-17] and more recently sprawl has been identified as a prime example of unsustainable urban development which must be minimized to promote sustainable communities $[18,19]$.

The legal problem starts with the 1926 United States Supreme Court decision holding that comprehensive zoning was a constitutional exercise of the police power. Euclid v. Ambler Real Company [20] allowed the segregation of multiple-family dwellings, which were seen as unhealthy urban tenements, from single-family dwellings. It thus enshrined the low-density, single-family house, protected from alien, lower land uses such as apartments, as the highest form of civilized land-use. Specifically, it allowed cities to adopt zoning ordinances which offered a limited range of residential choices and '[a]s a result, the new American city has been likened to an unmade omelet: eggs, cheese, vegetables, a pinch of salt, but each consumed in turn, raw' $[10,11]$. To continue the culinary analogy, planners describe American suburbs as afflicted with the BANANA syndrome (Build Absolutely Nothing Anywhere Near Anyone). For many years, these developments retarded the construction of 
higher density residential developments, although economic considerations eventually forced developers to demand the right to build more multiple-family housing.

The Supreme Court praised the newly developed 'science' of city planning. However, in practice land use planning became a strategy for accommodating unlimited growth rather than trying to control and contain it, except in wealthy communities which used conventional zoning, such as minimum lot sizes, to exclude multiple-family housing. Planners originally assumed that comprehensive plans could accurately project an area's future path of development, but plans could not tame the market. Instead, raw land was treated as a commodity and low-density zoning was seen as a holding zone until a development offer was made to the city. The idea of zoning as a stable set of regulations controlled by a master plan was quickly abandoned in favor of a system that characterized zoning as a bargaining process among developers, neighbors and the city [21]. Negotiated change became the prevailing norm and helped to dampen any expectations of a relatively stable landscape or that land-use controls would be subordinated to planning.

Endless suburbanization subordinated economic and social equity to individual choice. The aggressive promotion of suburbanization after World War II encouraged whites to flee center cities, and the United States is still struggling with this legacy. United States law forbids suburbs from excluding racial minorities [22], but the use of zoning to practice illegal racial discrimination is almost impossible to prove [23]. A few states have tried to increase the range of low- and moderate-income housing choice in suburban communities. Nonetheless, land-use still assumes that suburbs are autonomous units that owe few, if any, duties to coordinate their land-use policies with their neighbors, and thus can compete among themselves for whatever housing and social mix they desire [24,25]. Local autonomy was sealed by the United States Supreme Court, which held in 1974 that the duty to racially integrate schools was confined to a district's boundaries. There was thus no duty to integrate a metropolitan region [26].

\subsection{The Case against Sprawl}

There is considerable economic evidence supporting the conclusion that low-density growth imposes higher service costs on communities and causes substantial external costs. In addition, low-density, totally automobile-dependent growth is not sustainable. The automobile-dependent city uses too much energy compared to alternative land-use patterns and is a major source of air pollution [27]. For example, Kenneth Jackson celebrated the suburbs in his classic, The Crabgrass Frontier, but he predicted that '[b]y 2025 the energy-inefficient and automobile dependent suburban system of the American Republic must give way to patterns of human activity and living structures that are energy efficient'[28,29]. However, these efforts have not amounted to much, except in a few wealthy areas. As a country we still love sprawl [30], and the case against sprawl is partially an aesthetic and value judgment about high-versus low-density development. Thus, there is no single, simple solution because the legal and cultural support for sprawl is so deep [31,32].

The case against sprawl is part of a larger debate about ideal settlement patterns. Three normative models of the urban form have dominated United States planning discourse - the continental European city [33], the English village and the low-density American suburb. Others have collapsed the three models into two, 'the traditional neighborhood' and 'suburban sprawl' [11]. Planners have long 
advocated that we adopt the continental European [34] or the English village model of the city, which can roughly be defined as a centralized, dense mix of commercial and residential development, pedestrian access to vibrant shopping, effective public transportation networks, diverse and high abundant leisure activities, cultural venues and appropriately scaled public spaces [35]. Until the past three decades, developers, politicians and citizens have largely rejected this model as unsuited to the American experience of endless cheap land [36]. American cities did not grow out of the tight mediaeval European castle, cathedral and market towns, and thus these urban forms and their neatly demarcated rural boundaries are not symbols of this country's soul. One could not write this statement of American cities. However, in recent decades, there has been a lessening of this bias and considerable 'Europeanization' of American cities [37,38]. This trend is the intellectual foundation for efforts to reduce automobile $\mathrm{CO}_{2}$ emissions.

\section{California Tackles Sprawl: From Direct Regulation of Emissions to CEQA Litigation}

\subsection{AB 32: The First Step}

Were California a nation, it would be the world's eighth largest economy and the 12th biggest carbon emitter. The state is also likely to experience a substantial rise in temperature with severe impacts ranging from sea level rise to less available water to send from the relatively wet north to the arid south. After the actor Arnold Schwarzenegger became governor, he pledged to make the state a leader in GCC mitigation. The first fruit of this pledge was AB 32.

$\mathrm{AB} 32$ requires the California Air Resources Board (CARB) to adopt rules for the major sources or categories of greenhouse gas to achieve the maximum technologically feasible and cost-effective reductions [39] before January 1, 2011. The rules will become operative on January 1, 2012 [40]. The legislation also required the CARB to adopt early action reduction measures by June 30, 2007 that could be implemented ahead of the 2011 regulations, for which regulations are to be put into place and enforceable no later than January 1, 2010 [41]. In December, 2007, the Board adopted the mandatory reporting regulations applicable to large facilities [42].

California's 1990 greenhouse gas emissions were 427 million metric tons of carbon dioxide equivalent [42]. Data sources compiled to arrive at that figure included fuel combustion, industrial processes, and agricultural practices. The transportation sector, not surprisingly, was the largest contributor to these emissions, equaling 35 per cent of the state's total emissions [42]. The remainder of the inventory for 1990 attributed the remaining percentages as follows: industrial emissions, 24 per cent; imported electricity, 14 per cent; in-state electricity generation, 11 per cent; residential use, 7 per cent; agriculture, 5 per cent; and commercial uses, 3 per cent [42].

The Board estimated that emissions in 2020 could be as much as 600 million tons of carbon dioxide equivalent if no mitigating actions are put into place [42], but concentrated on the reduction of 107 million tons of carbon dioxide equivalent, because it anticipated that roughly 66 million tons of carbon dioxide equivalent would be reduced as a result of tailpipe regulations and development of low carbon fuels [42]. In September 2004, the CARB approved and adopted emissions regulations affecting passenger cars, light-duty trucks, and medium-duty passenger vehicles that would be certified for sale in California beginning with the model year 2009 [43]. The regulations required declining average emissions of certain greenhouse gases from new vehicles. In order to enact more 
stringent emission standards, however, CARB had to seek a waiver under the Clean Air Act from EPA's Administrator.

Section 209(a) of the Clean Air Act provides that States may not adopt any standard relating to the control of new motor vehicle emissions [44]. However, Section 209(b) provides that the EPA Administrator may waive the application of Section 209(a) to a State which has adopted its own standards, so long as the State has determined that its standards will be at least as protective of the public health and welfare as Federal standards [45]. The Administrator may deny such a waiver only when he or she finds that the State's determinations are arbitrary and capricious, the State does not need the regulations to meet compelling and extraordinary interests, or the State's standards are inconsistent with the Federal regulations under the Clean Air Act. The Bush Administration denied the waiver [45,46], California filed suit against the EPA challenging the denial, [47] and the Obama Administration EPA approved the waiver in July of 2009 after President Obama instructed the administrator of the EPA to reconsider the denial. California will thus benefit from the increased Corporate Advantage Fuel Economy (CAFÉ) standards. These standards have been in place since 1975 [48], and in 2007 Congress raised them for the first time since 1990 to $35 \mathrm{mpg}$ for cars and light trucks by 2020 [49]. In response to Massachusetts v. EPA [50], President Obama brokered an agreement among the automobile industry, federal officials and California which modestly raised the standards to $35.5 \mathrm{mpg}$ by 2016.

\subsection{Beyond the Internal Combustion Engine to Modifying Driving Patterns}

Legislation such as AB 32 presents real implementation problems because achieving the statute's purpose requires bringing the issue down to the level of individual behavior [51,52]. Initially, the waiver was California's only strategy to address transportation emissions. To make further reductions, the issue of driving behavior would have to be addressed. This could be done through high European-level taxes on gasoline but so far all levels of government have resisted this and followed the traditional goal of providing the cheapest energy possible to consumers. A massive shift from the automobile to public transportation might help, but so far the state's limited light- and commuter-rail services serve only a very small fraction of the population and are designed primarily to take commuters to work and back during the week. There are no network systems such as one finds in Europe which enable people to move quickly about an area for leisure as well as work. Thus, encouraging more dense development linked to existing public transportation nodes remained the only realistic option.

\section{A County Forced to Consider GCC Mitigation Strategies}

\subsection{The Law Suit}

Given California's sprawling urban areas both along the coast and in the Central Valley, controlling suburban sprawl is a Sisyphean task for the state. As have most states, the legislature has delegated land-use controls to counties and cities. State enabling legislation controls the structure of regulation and the content of mandatory plans, but there is very limited state preemption. Thus, there was real risk that $\mathrm{AB} 32$ would never be effectively implemented and would fall into the category of 
'aspirational' legislation. However, two important things happened in California. First, non-governmental organizations and the state were able to use the California Environmental Quality Act [53] (CEQA) to help achieve the goals of AB32 by reducing gas emissions stemming from land use and development. Second, the legislature passed new legislation to directly address the sprawl-automobile use link.

The first county targeted was San Bernardino County. At a size greater than nine of the smallest states (or a little over 19 times the size of Rhode Island), San Bernardino's 20,160 square miles stretch from Los Angeles County's eastern border to the western border of Nevada and the Colorado River border of Arizona. Despite the desert-mountain geographic dichotomy of San Bernardino's land area, its population doubled between 1980 and 2000, growing from 919,700 residents to over 1.7 million [54]. And, today the population is roughly 2 million [55]. The county has a very low-density average of roughly 100 people per square mile, although there are vast uninhabited areas of San Bernardino County, such as portions of the Mojave Desert, which distort the low-density average. Moving beyond mere averages, many previously unpopulated areas or very low-density areas are among the nation's fastest growing cities. For instance, more than 70 per cent of the housing units in high desert areas like Victorville and Hesperia were built since the 1980s, and the vast majority of the housing is single-family detached residences with no effective public transportation system. While several public transportation entities support some areas of San Bernardino County, public transportation is not the central mode of transportation. On average, the various bus systems provide only 8 or 9 rides per resident per year [56]. The major commuter train which connects the outer lying areas to the Los Angeles region, for instance, does not reach most of the fastest growing areas of the county [57], leaving residents no other option but to drive their vehicles into work or at least into the commuter station. Brenden Cummings, a senior attorney for a regional NGO, the Center for Biological Diversity, summed up why San Bernardino was an easy target for a law suit: 'San Bernardino has never seen a project it didn't like ... They rubber-stamp development. It's very much of a frontier mentality' [58].

After the Center for Biological Diversity filed suit against San Bernardino County, the Attorney General of California joined the suit. In 2007, State of California in California v. County of San Bernardino petitioned the Superior Court to order San Bernardino County to address greenhouse gas emissions in the preparation of its update to its general land-use and development plan [59]. The state alleged that the County had failed to disclose reasonably foreseeable effects of the plan on increased emissions and had failed to adopt appropriate mitigation of greenhouse gas emissions. The suit was quickly settled, as will be discussed below, but the suit will serve as a model for other litigation.

\subsection{California Environmental Impact Assessment Law and GCC}

California's "little NEPA," the California Environmental Quality Act [CEQA], is stronger than the federal National Environmental Policy Act because it applies to local as well as state activities and it is substantive. NEPA is purely procedural and thus creates an incentive to disclose all adverse environmental impacts without taking meaningful action to mitigate them. In contrast, the basic purpose of CEQA is to identify ways in which environmental damage can be avoided or reduced through the use of alternatives or mitigation measures [60]. A public agency must mitigate or avoid effects on the environment whenever it is feasible to do so [61]. A general land-use and development 
plan is subject to CEQA regulations as a 'project' within the meaning of the act [62]. If the 'project' may have a significant effect on the environment, an Environmental Impact Report [EIR] is required [63]. A significant effect on the environment is defined as 'a substantial, or potentially substantial, adverse change in any of the physical conditions within the area affected by the project, including land, air, water, minerals, flora, fauna, ambient noise, and objects of historic or aesthetic significance' $[64,65]$.

The purpose of the EIR is to provide both public agencies and the public in general detailed information about possible environmental effects [66]. Thus, the EIR process is an opportunity to put items such as global climate change on the agenda of the local and state agencies which have the power to take steps to address the problem. However, the EIR process in California suffers from two problems, one specific to the state and the other endemic to environmental impact analysis. The United States Supreme Court has interpreted NEPA to impose only procedural rather than substantive mandates on federal agencies [67]. In contrast, CEQA imposes a substantive mitigation requirement on state agencies unless feasible measures are unavailable [68]. California's emphasis on mitigation encourages the agency to find a one-off solution that reduces a limited range of adverse impacts. More generally, there are no limits to the range of issues that could be addressed with respect to global climate change. Not surprisingly, however, the courts have limited the scope of EIRs.

The fate of an intermediate appellate court's attempt to force decision makers to use the EIA process to confront the root causes of a problem illustrates the discretion the law places on those responsible for an EIS to narrow the scope of reports. In California, the northern part of the state produces most of the state's annual water supply, but much of this water is sent to the dry central and southern parts of the state where most of the major agricultural districts and population centers are located. A casualty of this policy is the Bay-Delta ecosystem, where the state's two major internal rivers empty into the Pacific Ocean. In the 1990s a stakeholder process, CALFED, was formed to address the tension between conserving the ecosystem and supporting continued water exports.

In 2000, the process produced a set of recommendations supported by an EIR. An intermediate appellate court remanded the EIR, in part, because 'CALFED appears not to have considered, as an alternative, smaller water exports from the bay-Delta region, which might, in turn, lead to smaller population growth due to the unavailability of water to support such growth.' The state Supreme Court reversed that heretical decision and held that the purpose of the process was to balance the tension between ecosystem conservation and water exports, and thus the report did not have to consider an alternative that would impede the attainment of the export objective [69].

The major limitation applicable to a full analysis of climate change impacts is the distinction between likely foreseeable future impacts and speculative ones. If impacts are foreseeable from the project, then those impacts must be analyzed and cannot be dismissed as speculative [69]. In other words, an agency must use its best efforts to identify the impacts and disclose its analysis to the public [69]. It is not easy to draw the line between the speculative and the foreseeable. To draw upon an example from another state, in Pennsylvania, a landowner can be compelled to connect to public water systems for health reasons, but a landowner in that state refused to do so because of the potential of post $9 / 11$ terrorist threats. A state court rejected this defense, concluding that there is no imminent risk and that a city does not have a duty to guarantee that terrorists, who are private actors, will not contaminate a water supply [70]. The same problem applies to climate change. Scientists have a 
general idea that continued greenhouse gas emissions on a world-wide scale will affect future climate change, but it is still difficult to project regional impacts, thereby making it difficult to provide the requisite detailed information. The California Environmental Law and Land-Use Practice guide suggests that if a particular impact is too speculative for evaluation, the Agency need not discuss it at length and may merely note its conclusion [71].

The Association of Environmental Professionals has issued a 'white paper' which suggests that there are a number of possible responses to a demand that a project be evaluated for its possible effect on global warming [72]. They suggest at one end that it is possible to give no response at all. And, at the other extreme, they suggest that a full analysis and mitigation plan could be prepared [73]. There is a growing case law on the consideration of climate change in EIAs but the precedents give no clear answer on how far into the future an EIS is required to venture. Still, the law's uncertainty allows NGOs to continue to push the GCC envelope.

The case of Natural Resources Defense Council v. Reclamation Board of the Resources Agency of the State of California [74] illustrates the opportunities available to NGOs. The petitioners challenged the Reclamation Board's approval of two 'fill and encroachment permits' related to the development of the River Islands at Lathrop project, which lies within the Sacramento-San Joaquin Delta region, an area at risk from floods and rising sea levels [74]. The permits would have allowed the permittees to place fill between an existing federal levee and an interior private levee, thereby creating a 'super levee,' and to place structures on top of a portion of the levee [74]. The petitioners argued that the respondent failed to prepare a full subsequent or supplemental EIR before approving the fill and encroachment permits [74]. They dealt with the uncertainty problem by arguing that further review was necessary to take into account new information regarding the impact of climate change on the region where the project is located [74]. Thus, this litigation is a twist on the EIR concept, which asks what effect the project will have on the environment. It instead asks what effect the environment will have on the project in future years. According to the NRDC attorney, as quoted by Carbon Control News, this type of litigation is meant to '[force] people to think about what the world will look like in 50 years' and 'the strategy recognizes that some degree of climate change will be a reality and that we need to start grappling with its impacts' [75].

The petitioners relied on five new sources of information in an attempt to get the Court to recognize that a subsequent EIR was in order: (1) the California Department of Water Resources California Water Plan Update, dated December, 2005; (2) the CalEPA Climate Action Team Report to Governor Schwarzenegger and the California Legislature dated March 2006; (3) testimony of California Department of Water Resources Director, Lester Snow, to the Subcommittee on Water Power, Committee on Resources of the U.S. House of Representatives, April 6, 2006; (4) California Department of Water Resources Report entitled 'Progress on Incorporating Climate Change into Management of California's Water Resources,' dated July 2006; and (5) a statement by the U.S. Environmental Protection Agency, which is working on a federal Environmental Impact Statement for the Paradise Cut improvements, that it will consider climate change and its effects on California hydrology and that existing analyses in the EIRs for the River Islands projects will not be sufficient [74].

Despite the wealth of additional information provided to it, the Court found the petitioner's arguments unpersuasive. Even if the Court were to assume that a 'scientific and political consensus 
regarding the existence and potential effects of climate change [had] grown significantly since mid-2005, petitioners have not presented any real new information' with respect to effects that could be expected in the area of the Delta where the project is located [74]. The Court noted that the studies and information supplied by the petitioner provided generalized information regarding the potential effects of climate change on the entire State or region but not as to the specific project site itself. Thus the Court found that the petitioners had not demonstrated that any 'significant new information' of climate change on the particular project had become available that would have required a full EIR prior to approving the permits [74]. The court did note, however, that it was limiting its ruling to the facts of that case and that climate change is likely a proper factor to be considered under CEQA. Nevertheless, the ruling in this case suggests that until the science of climate change improves such that regional impacts can be more easily gauged, it will not be easy to challenge determinations of no significant impact.

Other California cases have also found that impacts of climate change are yet too speculative. In American Canyon Community United for Responsible Growth v. City of American Canyon, the Napa County Superior Court, found that the AB 32 legislation is not reason enough to require greenhouse gas emission analysis under CEQA [76]. In Santa Clarita Oak Conservancy v. City of Santa Clarita, the Los Angeles Superior Court, on August 15, 2007, upheld an EIR for an industrial park which concluded that the impact of climate change on water supply was too speculative.

The major problem with these recent cases is that they seem to discount the fact that ' $[0]$ ne of the most important environmental lessons evident from past experience is that environmental damage often occurs incrementally from a variety of small sources ... perhaps the best example is air pollution, where thousands of relatively small sources of pollution cause a serious environmental health problem' [77]. It is becoming apparent that greenhouse gases and climate change are surpassing simple air pollution as the quintessential incremental killer of our environment. In addition, these cases fail to acknowledge that CEQA is also meant to address cumulative effects.

In addition to the problem of speculation, the duty to discuss cumulative impacts presents another line-drawing issue. An EIR must address cumulative impacts by addressing incremental changes posed by a single project or land-use plan. A significant effect on the environment may also exist if 'the possible effects of a project are individually limited but cumulatively considerable' [78]. 'Cumulatively considerable' is defined to require 'that the incremental effects of an individual project are considerable when viewed in connection with the effects of past projects, the effects of other current projects, and the effects of probable future projects' [78]. According to the California Environmental Law and Land-Use Practice guide, this means that an agency must evaluate related projects and determine how the instant project along with related projects will affect the environment.

However, CEQA seems to suggest that cumulative impacts must be evaluated only by looking at directly neighboring projects. Under California's Administrative Code, a cumulative impact assessment must contain 'either a list of past, present, and reasonably anticipated future projects, including those projects outside the agency's control, which produce related or cumulative impacts or a summary of such projections contained in an adapted general plan or related planning document which evaluates regional or area-wide conditions,' plus a summary and analysis of the expected effects [79]. The provision suggests that a cumulative impact assessment must only take into account discernible projects or projections contained in a land-use and development plan. If so, it leaves us 
wondering whether the Courts will continue to condone dismissing applications of climate change to regional impacts as too speculative, finding, perhaps, that any incremental change, even if considered cumulatively with an entire region, is nevertheless de minimis in comparison to the total of greenhouse gas emissions which are responsible for climate change.

On the other hand, an agency does have some discretion to determine the appropriate geographic study area to take into consideration for cumulative impacts, such as determining assessment areas for cumulative impacts on a particular wildlife species [80]. However, in the past, Courts have not entirely deferred to an agency's choice of study area. For instance, in Kings County Farm Bureau v. City of Hanford, the Court concluded that including only 30 power plants instead of 116 resulted in an unacceptable underestimation of cumulative impacts [77]. Given the scale of urban development that contributes to $\mathrm{CO}_{2}$ emissions, decisions which limit the ability of cities to narrow the geographical scope are a positive step in California's efforts to address climate change through land use planning.

In addition, not all cases have interpreted CEQA to limit the assessment of an incremental change to comparisons with only other discernible projects or land-use plan projections. In Los Angeles Unified School District (LAUSD) v. City of Los Angeles, the City evaluated traffic noise, but failed to determine the cumulative significance of existing and increased traffic noise [81]. The court held that the 'issue to be addressed in the EIR on the plan is not the relative amount of traffic noise resulting from the project when compared to existing traffic noise, but whether any additional amount of traffic noise should be considered significant in light of the serious nature of the traffic noise problem already existing around the schools' ([81], p. 1025). Thus, the Court compared the addition of an environmental effect to an existing problem that was posed not by any other particular project or other future projects, but simply by an existing environmental problem that the area already faced.

However, what distinguishes LAUSD v. City of Los Angeles, perhaps, from potential climate change cases, is the finding that noise impact was not too speculative for evaluation, and that data was available to support a meaningful discussion of the impact ([81], p. 1027). In the case of climate change, it is arguable that while data can be relatively easy to garner with respect to potential greenhouse gas emissions posed by the project, the science of using that data to project its effect on climate change is still too tenuous to allow any meaningful discussion of the impacts, at least at a regional level. Nonetheless, it could be argued that the current warming trend, which is apparent throughout the globe, is a pre-existing condition with imminent effects to which any increase of precursors would be significant.

In response, agencies could argue, that the 'sufficiency of an EIR should be reviewed in light of what is reasonably feasible and that perfection is not required' [82]. In addition, they could argue that an EIR must have a meaningful analysis of the alternatives in order for the courts and the public to fulfill their roles in the CEQA process [83]. And, the 'EIR must contain facts and analysis, not just ... bare conclusions or opinions' [83]. As already discussed above, the California Courts have agreed with these types of arguments, finding the calculation of regional impacts from climate change is somewhat infeasible. To incorporate calculations of incremental climate change impacts of regional emissions in comparison to worldwide emissions does seem unworkable for the CEQA process. The CEQA process is burdensome as it is, without having to incorporate calculations of worldwide emission sources in order to determine potential cumulative impacts of any one project. Still, any additional anthropogenic $\mathrm{CO}_{2}$ input at this point in time logically appears cumulative and relevant to a CEQA analysis because 
we know that the persistent nature of $\mathrm{CO}_{2}$ in the atmosphere means any additional $\mathrm{CO}_{2}$ emissions pose a threat that is barely short of permanent. The largest barrier to the implementation of any sub-national climate change adaptation program is the inability of models to bring impacts down to a regional or smaller scale. However, this should not be used to excuse local governments from assessing the projected $\mathrm{CO}_{2}$ emissions by ensuring that future development minimizes them and thus the question of the geographical scope of the reduction is irrelevant.

At least two counties in California agree with this analysis. They have determined that assessing regional impacts of climate change is currently infeasible, yet they nevertheless require greenhouse gas emissions to be taken into special consideration because of the drastic implications any additional contribution of greenhouse gases poses. Kern County and Placer County have taken the stance that every project's contribution of greenhouse gas emissions represents a cumulative contribution and thus a significant cumulative impact. Kern County, at the South End of the Central Valley, requires that every project which emits $\mathrm{CO}_{2}$ or methane prepare an EIR and adopt a statement of overriding considerations [84]. Placer County, in its 'Second Partially Recirculated Draft EIR' for the Placer Vineyard Specific Plan, found that despite mitigating factors, the impact of greenhouse gas emissions was significant [84]. The lack of standards for evaluating greenhouse gas emissions and the size of the project were part of what led these counties to use that approach.

Some lawyers have suggested that using the 'too speculative' card is the best procedure for now. The argument is that any attempt at quantifying greenhouse gas emissions before an accepted methodology is published would invite further challenges to the EIR. In addition, it might lead to unfair comparisons between projects, each of which would be likely to use a differing methodology [84]. The California Attorney General's office, on the other hand, believes that determining the significance of a project's effects on climate change can be simply accomplished in light of the policy enunciated in AB32. Lack of regulatory guidance with respect to calculating significance thresholds is arguably immaterial. A recent settlement with Conoco/Phillips will require the company to offset greenhouse gas emissions from an expansion project; but the Attorney General commented that the 'lack of guidelines does not excuse the County from analyzing whether or not this increase [of emissions] would be 'significant' for CEQA purposes' [85]. The argument for considering greenhouse gas emissions in an environmental impact assessment is that AB 32 implicitly creates a duty to monitor greenhouse gas emissions generally. Thus the EIR should determine what potential the project has for reducing the likelihood that the 1990 greenhouse gas emission levels will be reached by 2020 [73].

\subsection{The Settlement of the Litigation}

The California Attorney General used the above analysis to criticize the EIR prepared by San Bernardino County for its updated land-use and development plan. Without answering whether AB 32's policy is a valid basis for finding a significant environmental impact, the parties in California v. County of San Bernardino quickly agreed to settle the case [86]. The settlement establishes a unique greenhouse gas reduction plan. The plan requires a baseline inventory of 1990 greenhouse gas emissions and a projected inventory of reasonably discoverable sources of greenhouse gas emissions [86]. The County is required to estimate 2020 emissions and develop a target for reducing 
emissions attributable to the County's discretionary land-use decisions [86]. The agreement also provides that the County's compliance with $\mathrm{AB} 32$ or its governing regulations shall be deemed to constitute compliance with the agreement to the extent the agreement in any way conflicts with these regulations [86]. The State of California has even agreed to help find funding to offset the County's compliance costs [87]. The County has until February 2010 to comply (30 months from the execution of the agreement). A number of other counties are allegedly following suit by initiating their own greenhouse gas reduction measures [87].

Ultimately, however, developing a workable strategy for addressing climate change strategy using CEQA is tenuous. CEQA only gets you so far for now. While it might be reasonable to require that an agency or developer assess the greenhouse gas emissions expected as a result of the general plan or project, CEQA potentially breaks down at the point of determining whether the amount of expected greenhouse gas emissions poses a significant environmental impact. It is difficult to determine what amount is significant when you are talking about gases that cumulatively have a global impact. Thus, it is seemingly impossible to then determine what level of mitigation is required to reduce emissions to levels which are not significant [88].

\subsection{Post Settlement Legislation}

The litigation described above helped to spur the passage of legislation that many considered unthinkable. The settlement set an important precedent but did not create uniform planning duties. Cities still had a considerable incentive to continue to plan for expansion and wait for opposition. This changed with the passage of Senate Bill 375. The duty to use land-use controls to curb greenhouse gas emissions is now mandatory. The new statute sets regional roll-back targets and then mandates local implementation. First, the State Air Resources Board must set regional vehicle greenhouse gas emissions targets. Second, each metropolitan planning organization in the state must prepare a sustainable community plan which the Board can review for consistency with the targets. Third, the legislation provides an incentive for local communities to be proactive by adopting growth plans that concentrate new development around public transportation nodules, which actually exist in the four major urban areas of the state- the San Francisco Bay Area, Sacramento, the Greater Los Angeles area, and San Diego on the Mexican border. Cities which cluster growth along priority transportation corridors through mixed-use, higher-density in-fill and/or transportation-oriented residential development may seek an exemption from CEQA review. This is the first major United States legislation that seeks to reverse urban sprawl to decrease the increase of greenhouse gas emissions [88].

The legislation has empowered a government agency, the Office of the State Attorney General, which has not historically taken an active role in land-use issues, to intervene in planning decisions and to link greenhouse gas mitigation with another important social objective, the provision of low and moderate income housing. For example, shortly after the passage of Senate Bill 375, the State Attorney General wrote to a rapidly growing community, Pleasanton, which is on the edge of the San Francisco Bay Area, objecting to three aspects of the Draft Environmental Impact Review prepared for the update of its general land-use plan. The city had adopted a cap on housing, but the Attorney General found this inconsistent with its inclusionary duties. 'By relying of the Housing Cap (29,000 units) as a justification for preventing more residential units, the City ignores its 
obligation to provide for sufficient housing for the region's growing population.' Local housing caps also actually exacerbate greenhouse gas emissions because people are pushed further into the outer reaches of the metropolitan area to find affordable housing and they must often drive longer distances to work.

The city's efforts to factor climate change into its planning were found unacceptable for several reasons. First, the city allowed 35,000,000 square feet of commercial space, which set 'an unacceptable jobs/housing imbalance ... exporting air pollution, exacerbating already horrendous traffic jams, and promoting greenhouse gases.' Second, 'The DEIR fail[ed] to sufficiently [sic] identify, analyze, or mitigate climate change impacts associated with the proposed buildout ... The job/housing imbalance... would result in a 46\% increase in Vehicle Miles Traveled' [89]. Third, the city's finding that its plan would have no significant climate change impacts was 'flawed' because there is no estimate of current greenhouse gas emissions and because the city used projections from the 1996 plan, 'not actual conditions existing today' [90].

\section{Marin County: A Case Study of Using Land-Use Regulation to Curb Climate Change}

Some counties have already recognized that comprehensive land-use planning may be the better, more comprehensive tool for reducing greenhouse gas emissions. Marin County, a wealthy, progressive county over the San Francisco Golden Gate Bridge, for instance, has adopted a new general plan which takes greenhouse gas emissions into account [91]. It does so much differently from San Bernardino's Settlement Agreement with the state, which calls for a separate Greenhouse Gas Emissions Reduction Plan. The Marin County General Plan uses sustainability as an underlying theme throughout [92]. The plan even calculates the ecological footprint of the average resident and includes measures to reduce the footprint [92]. It is allegedly the first local comprehensive plan in the country to use such an approach [92]. Other counties are following suit. Butte County, as well, is using sustainability as an underlying theme or guiding principle in its ongoing update of a 30 -year-old general plan [92].

Sustainability principles may include more than just addressing greenhouse gas emissions, such as incorporation of water reuse systems. Yet the Marin Countywide Plan focuses largely on smart-growth initiatives that are intended, in large part, to reduce greenhouse gas emissions from transportation. This is particularly of interest in Marin County because the transportation sector was responsible for $62 \%$ of that County's greenhouse gas emissions during 2005 ([92], p. I-9). Marin County intends the general plan to encourage reduction of greenhouse gas emissions from the transportation sector in a number of ways ([92], p. 2-104).

Interestingly, many of the action items in Marin County's Plan are woven into a section addressing the goal of 'balanced communities' ([92], p. 3-15). To achieve the goal of a balanced community, Marin County cites many policy initiatives, some of which are quite relevant to greenhouse gas reductions, such as establishing a housing overlay designation, locating housing near activity centers, focusing intensive development at nodes, enhancing existing commercial and industrial areas and businesses, and expanding countywide efforts to increase workforce housing rather than full commercial build-out ([92], pp. 3-15-3-18). The greenhouse gas reduction effects possible as a result of some of these policies are self-evident in their title. For instance, locating housing near activity 
centers, and focusing intensive development at nodes of transportation, are approaches that hold out the promise of pedestrian-friendly neighborhoods and increased reliance on public-transit systems, both of which reduce reliance on gas-guzzling, greenhouse-gas-emitting vehicles. Other initiatives are not as clear in their title, but are just as potent in their likely effect. The housing overlay designation initiative encourages construction of housing for very-low- and low-income households close to transit, employment and public services ([92], p. 3-15). Enhancing commercial and industrial areas and business encourages mixed-use development ([92], p. 3-17). And, expanding the effort to increase workforce housing encourages housing development near employment centers and public transportation [92]. Overall, it appears the County has a deep commitment to reducing traffic congestion and, as a result, decreasing its greenhouse gas emissions.

Specifically, Marin County intends to identify and plan mixed-use sites and promote redevelopment of sites. In addition, it plans to use zoning to accomplish many of its policy goals. It plans to rezone lands to accommodate mixed housing types and densities. In addition, it will 'require new commercial developments (including major remodels of shopping centers) to integrate housing that will reduce the need for commuting and expand the opportunities for residential development' ([92], p. 3-19). And, it will zone to encourage nodes of commercial and higher-intensity residential development near employment bases that can be served by public transit. In addition, the plan calls for limiting density for areas without water and sewer connections, by calculating density at the lowest end of the Countywide Plan designation range for subdivisions proposed in areas without public water and/or sewer service ([92], 3-29). As a complement to steering density away from more rural areas, the plan calls for creating a transfer of development rights program. The program would enable transfer of development rights from bay-front or greenbelt areas to medium- and higher-intensity centers.

\section{Conclusions}

The state of California has embarked on an ambitious experiment to mitigate greenhouse emissions by linking settlement patterns and driving patterns [93]. This experiment has several notable lessons for other areas. First, it illustrates that sub-national units have important roles to play in GCC mitigation [94]. These units are the logical choices to address transportation mitigation. Second, the California experience illustrates that environmental laws and litigation techniques developed prior to the recognition that we need new national and international legal regimes to mitigate to GCC can be adapted to this objective. Third, the experiment illustrates an important evolution of environmental law. At the beginning of the environmental movement, polluters were the 'other.' Industry and cities were the villains and strong government action was necessary to modify their behavior. There was little role for the individual as the few deep ecologists who preached reduced consumption were marginalized. As we address issues such as energy consumption and global climate change, the question of how to modify individual resource consumption has become critical [77], and California is trying to push localities to adopt land-use patterns that force individuals to modify their driving habits and the consumption of gasoline. 


\section{References and Notes}

1. Professor Tarlock presented a partial version of this paper at a seminar in the Center for Urban and Regional Studies in the School of Architecture and Town Planning, Technion, Haifa, Israel, 1 July 2009, and he thanks Professor Rachelle Alterman, head of the center for Urban and Regional Studies for organizing the seminar.

2. Bosselmann, K. Ecological Justice and Law. In Environmental Law for Sustainability; Richardson, B., Wood, S., Eds.; Hart Publishing: Oxford, UK, 2006; Volume 129, pp. 150-155.

3. See Weston, B.H.; Bach, T. Recalibrating the Law of Humans with the Law of Nature: Climate Change, Human Rights, and Intergenerational Justice; Vermont Law School: South Royalton, VT, USA, 2009; Available online: http://international.uiowa.edu/centers/human-rights/documents/ CLI_Policy_Paper.pdf (accessed on 17 May 2010). The ethical duty to practice sustainable development is complemented by the intergenerational equity principle which posits "that future generations ... have a legal right to ecological protection" which includes the projected adverse consequences of global climate change (GCC).

4. In July 2009, the United States House of Representatives passed weak greenhouse gas emission reduction legislation, but as of December, 2009, the United States had not acted on the Senate version of the bill.

5. The American Clean Energy and Security Act of 2009; An Energy Bill in the 111th United States Congress (H.R.2454); Approved by the House of Representatives on 26 June 2009.

6. Cal. Health \& Saf. Code $\$ 38500$, et seq.; West's Annotated California Codes: Eagan, MN, USA, 2007.

7. Cal. Health \& Saf. Code \$38550; West's Annotated California Codes: Eagan, MN, USA, 2007.

8. Cal. Health \& Saf. Code \$38530; West’s Annotated California Codes: Eagan, MN, USA, 2007.

9. Inventory of U.S. Greenhouse Gas Emissions and Sinks: 1990-2008, Executive Summary; US Environmental Protection Agency: Washington, DC, USA, 2010; Available online: http://epa.gov/climatechange/emissions/downloads10/US-GHG-Inventory-2010_Executive Summary.pdf (accessed on17 May 2010).

10. Buzbee, W.W. Urban Sprawl, Federalism and the Problem of Institutional Complexity. Fordham Law Rev. 1999, 68, 57-136.

11. Duany, A.; Plater-Zyberk, E.; Speck, J. Suburban Nation; North Point Press: New York, NY, USA, 2000.

12. These policies, many of which are highly debatable, include (1) the high cost of car ownership and operation, (2) subsidies to promote agricultural land retention, and (3) central government provision of many urban services. Nivola, P. Are Europe's cities better? The Public Interest, Fall 1999, No. 137; Available online: http://www.nationalaffairs.com/public_interest/detail/ are-europes-cities-better (accessed on 17 May 2010).

13. Montiero, T.L.M. Preserving Europe's Heritage: Biodiversity, Landscape, and Agri-cultural Policy in Confederated Europe. Environ. Law Report. News Anal. 2005, 35, 10065-10072. 
14. An urban historian has criticized the model of the city adopted by new urbanists as "a kind of City Life" that celebrates consumerism at the expense of citizenship. Bender, T. Toward a New Metropolitanism and a Pluralized Public? In Proceedings of an International Conference on Towards a New Urbanism, Berlin, Germany, 29 June-1 July 2000; Available online: http://www2.rz.hu-berlin.de/amerika/projects/newurbanism/nu_pt_bender_a.html (accessed on 17 May 2010).

15. Our Built and Natural Environments: A Technical Review of the Interactions between Land Use, Transportation, and Environmental Quality; EPA 231-R-01-002; US Environmental Protection Agency: Washington, DC, USA, January 2001; Available online: http://www.epa.gov/dced/ pdf/built.pdf (accessed on 17 May 2010).

16. Ewing, R.; Pendall, R.; Chen, D. Measuring Sprawl and Its Transportation Impacts. Transp. Res. Rec. 2003, 1831, 175-183.

17. Gallagher, P. The Environmental, Social, and Cultural Impacts of Sprawl. J. Nat. Resour. Environ. 2001, 15, 219-223.

18. Dernbach, J.; Bernstein, S. Pursuing Sustainable Communities: Looking Back, Looking Forward. Urban Law. 2003, 35, 511-512.

19. Kaswan, A. Climate Change, Consumption, and Cities. Fordham Urban Law J. 2009, 36, 253-319.

20. 272 U.S. 365 (1926); United States Supreme Court: Washington, DC, USA, 1926.

21. In his important study of Illinois land use, the eminent United States land-use scholar Fred Bosselman concluded that the law remains to large extent the product of nineteenth century attitudes "which caused its residents to view land itself simply as another form of capital that could be made 'abstract, standardized and fungible' through the 'alchemy' of commodification". Bosselman, F.P. The Commodification of Nature's Metropolis: The Historical Context of Illinois Unique Zoning Standards. North Ill. Univ. Law Rev. 1992, 12, 527-588.

22. Village of Arlington Heights v. Metropolitan Housing Development Corp. 429 U.S. 252 (1977); U.S. Supreme Court: Washington, DC, USA, 1977.

23. The current Supreme Court's indifference to not-so-subtle racial discrimination is illustrated by City of Cuyahoga Falls v. Buckeye Community Hope Foundation, 123 S.Ct. 139 (2003) (city's processing of referendum which targeted a low-income housing project and was tainted by discriminatory purposes was not an unconstitutional violation of developer's rights).

24. Village of Belle Terre v. Boraas, 416 U.S. 1 (1974). The creation of independent suburbs with no duties to the larger urban region became after the Civil War.

25. Keating, A.D. Building Chicago: Suburban Developers and the Creation of a Divided Metropolis; University of Illinois Press: Champaign, IL, USA, 2002; pp. 79-118; Traces the evolution of the Chicago metropolitan area, which does not differ significantly from other similar United States areas. She identifies that passage of a general incorporation law in 1872 as the major factor in substantially confining Chicago's spatial growth to its present boundaries by the end of the 19 th century.

26. Milliken v. Bradley. 418 U.S. 717 (1974); U.S. Supreme Court: Washington, DC, USA, 1974.

27. Davis, J.S.; Seskin, S. Impact of Urban Form on Travel Behavior. Urban Law. 1997, 29, 215-232. 
28. Jackson, K.T. The Crab Grass Frontier: The Suburbanization of the United States; Oxford University Press (USA): New York, NY, USA, 1985; p. 304.

29. For a more recent articulation of this position see Ziegler, E.H. American Cities, Urban Collapse and Environmental Doom. Plan. Environ. Law 2008, 60, 4-9.

30. There has been a spate of recent "revisionist" scholarship which takes a much more favorable view of the suburban experience compared to most land-use planners and urban historians. See Garnett, N.S. Save the Cities, Stop the Suburbs? Yale Law J. 2006, 116, 598-630 for a critical review of this literature.

31. The structural reasons for sprawl are well-addressed in Buzbee, W.W. Urban Sprawl, Federalism and the Problem of Institutional Complexity. Fordham Law Rev. 1999, 68, 57-136.

32. Tarlock, A.D. Fat and Fried: Linking Land Use Law, the Risks of Obesity, and Climate Change. Pitt. J. Envtl. Pub. Health L. 2009, 3, 31-55.

33. Belmont, S. Cities in Full: Recognizing and Realizing the Great Potential of Urban American; APA Planners Press: Chicago, IL, USA, 2002.

34. Bertaud, A. The Spatial Structures of Central and Eastern European Cities: More European than Socialist? Available online: http://alain-bertaud.com/AB_Files/AB_Central\%20European\%20 Spatial\%20Structure_Figures_2.pdf (accessed on 17 May 2010); Defines a classic european city as "a dominantly monocentric structure with a center where exceptionally rich cultural amenities and prestigious retail reenforce its monocentric character. The monocentricity is maintained by prestigious amenities in spite of many jobs moving to the suburbs. As a corollary to the strongly attractive center, an efficient radial transit network make the center accessible even when many job commuting trips are made by individual cars from suburbs to cities".

35. Kunstler, J.H. Home from Nowhere; Touchstone: New York, NY, USA, 2000.

36. Potter, D. People of Plenty; University of Chicago Press: Chicago, IL, USA, 1954.

37. Many urban officials and planners have been influenced by the work of Richard Florida who argue that cities will only prosper if they provide the necessary public amenities to attract creative talents. e.g., Florida, R. The Rise of the Creative Class: How It's Transforming Work, Leisure, Community and Everyday Life; Basic Books: New York, NY, USA, 2002; Cities and the Creative Class; Routledge: New York, NY, USA, 2003; and Who's Your City?: How the Creative Economy is Making Where to Live the Most Important Decision of Your Life; Basic Books: New York, NY, USA, 2009.

38. More and more cities are also adapting to global climate change by adopting strategies pioneered in Europe. e.g., Beatley, T. Green Urbanism: Learning from European Cities; Island Press: Washington, DC, USA, 2000.

39. Cal. Health \& Saf. Code \$38560; West's Annotated California Codes: Eagan, MN, USA, 2007.

40. Cal. Health \& Saf. Code \$38562; West’s Annotated California Codes: Eagan, MN, USA, 2007.

41. Cal. Health \& Saf. Code \$38560.5; West’s Annotated California Codes: Eagan, MN, USA, 2007. 
42. Air Board Passes Two Major Building Blocks in State's Effort to Fight Global Warming; Release 07-59; Air Resources Board, California Environmental Protection Agency: Sacramento, CA, USA, 6 December 2007; Available online: http://www.arb.ca.gov/newsrel/nr120607.htm (accessed on 17 May 2010). (The largest facilities in the state, which account for 94 percent of industrial and commercial stationary source greenhouse gas emissions, will be required to report their greenhouse gas emissions on an annual basis beginning with emissions in 2008 to be reported in 2009).

43. California State Motor Vehicle Pollution Control Standards-Request for Waiver of Preemption Under Clean Air Act Section 209(b) for Greenhouse Gas Emissions; California Air Resources Board: Sacramento, CA, USA, 2006; Available online: http://www.regulations.gov/fdmspublic/ component/main?main=DocumentDetail\&d=EPA-HQ-OAR-2006-0173-0004 (accessed on 17 May 2010).

44. 42 U.S.C. $\$ 7543(a)$; Thomson-West: Eagan, MN, USA, 2003.

45. 42 U.S.C. $\$ 7543(b)$; Thomson-West: Eagan, MN, USA, 2003.

46. See also Notice of Decision Denying a Waiver of Clean Air Act Preemption for California's 2009 and Subsequent Model Year Greenhouse Gas Emission Standards for New Motor Vehicles. Federal Register 2008, 73, 12156-12169; Available online: http://wais.access.gpo.gov (accessed on 17 May 2010).

47. State of California v. United States Environmental Protection Agency. Petition for Review of Decision of the United States Environmental Protection Agency; US Environmental Protection Agency: Washington, DC, USA, 2 January 2008; Available online: http://ag.ca.gov/ cms_attachments/press/pdfs/n1514_epapetition-1.pdf (accessed on 17 May 2010).

48. 49 U.S.C. $\$ 32902$; Thomson-West: Eagan, MN, USA, 2003

49. Pub. L. 110-140 (2007); United States Printing Office: Washiongton, DC, USA, 2007.

50. 549 U.S. 497 (2007); United States Printing Office: Washiongton, DC, USA, 2007.

51. Environmental law was initially focused on the regulation of large emitters, but it is evolving toward the assignment of responsibility to individuals for their resource consumption decisions. Babcock, H.M. Assuming Personal Responsibility for Improving the Environment: Moving Toward a New Environmental Norm. Harvard Environ. Law 2009, 33, 117-175.

52. Vandenbergh, M.P.; Steinmann, A.C. The Carbon Neutral Individual. New York U. Law Rev. 2007, 82, 1673-1745.

53. California Environmental Quality Act, Public Resources Code $\$ 21000$ et. seq.; West's Annotated California Codes: Eagan, MN, USA, 2007.

54. County of San Bernardino, California, USA Homepage. http://www.co.san-bernardino.ca.us/ main/demographics.asp (accessed on 17 May 2010).

55. U.S. Census Bureau Population Finder Homepage. http://www.factfinder.census.gov (accessed on 7 June 2010).

56. According to the San Bernardino Associated Government's website, the various public transit authorities in the San Bernardino County region provide roughly 17.4 million rides per year. SANBAG: San Bernardino Associated Governments; Available online: http://www.sanbag. ca.gov/commuter/pub-transit.html (accessed on 17 May 2010). 
57. Metrolink makes only six stops in San Bernardino County in the cities of San Bernardino, Rialto, Fontana, Rancho Cucamonga, Upland, and Montclair, which are closest to Los Angeles County. No stops are made north, south, or east of the City of San Bernardino. Metrolink, San Bernardino Line; Available online: http://www.metrolinktrains.com/stations/detail.php?id=122 (accessed on 17 May 2010).

58. Ritter, J. Inland Empire's 25-year growth targeted. USA Today, 6 June 2007; Available online: http://www.usatoday.com/weather/climate/globalwarming/2007-06-05-warming-inside_N.htm (accessed on 17 May 2010).

59. The People of the State of California, ex rel. Attorney General Edmund J. Brown Jr. v. County of San Bernardino. No. CIVSS 0700329, Petitioner's Petition for Writ of Mandate; United States Supreme Court: Washington, DC, USA, 13 April 2007.

60. 14 C.C.R. \$15002; West's Annotated California Codes: Eagan, MN, USA, 2007.

61. Cal. Pub. Resources Code \$21002.1; West’s Annotated California Codes: Eagan, MN, USA, 2007.

62. Delaney, J.J. Climate Change and Sustainable Development. In Handling the Land Use Case: Land Use Law, Practice \& Forms, 3rd ed.; Thomson-West: Eagan, MN, USA, 2008; Part II, Subpart B, Chapter 42; (California v. San Bernardino is important for several reasons including that it 'confirmed that in California, a county's general plan is a "project" or 'undertaking' that is required to perform an environmental impact review under CEQA...').

63. Cal. Pub. Resources Code $\$ 21002.1$ and 14 C.C.R. $\$ 15064(a)(1)$; State of California: Sacramento, CA, USA; West's Annotated California Codes: Eagan, MN, USA, 2007.

64. 14 C.C.R. \$15382; State of California: Sacramento, CA, USA, 2007.

65. Courts have long remanded EIRs for the failure to discuss the air pollution impacts of land use location decisions. Bakersfield citizens for Local Control v. City of Bakersfield, 22 Cal.Rptr.3d 203 (Ct. App. 5th. Dist. 2004).

66. Cal. Pub. Resources Code \$21061; West’s Annotated California Codes: Eagan, MN, USA, 2007.

67. Strycker's Bay Neighborhood Council, Inc. v. Karlen. 444 U.S. 223 (1980); United States Supreme Court: Washington, DC, USA, 1980.

68. Cal.Pub.Res.Code \$ 21081; West's Annotated California Codes: Eagan, MN, USA, 2007.

69. In re Bay-Delta Programmatic Environmental Impact Coordinated Proceedings, 3rd ed.; The California Supreme Court: San Francisco, CA, USA, 2008.

70. Johnson v. Town of Plumcreek, 859 A.2d 7, 13 (Pa. Cmmw. Ct. 2004). There is a well developed law of the degree of probable injury required to have standing to challenge decisions of administrative agencies that may adversely impact the environment. Sturkie, C.; Seltzer, N.H. Developments in the D.C. Circuit's Article III Standing Analysis: When Is an Increased Risk of Future Harm Sufficient to Cause Injury-in-Fact in Environmental Cases? Environ. Law Report. News Anal. 2007, 37, 10287-10296.

71. 1-22 California Environmental Law \& Land Use Practice \$22.04, 11(c); M. Bender: Albany, NY, USA, 1989. 
72. Hendrix, M.; Wilson, C. Alternative Approaches to Analyzing Greenhouse Gas Emissions and Global Climate Change in CEQA Documents; Association of Environmental Professionals: Glendale, CA, USA, 29 June 2007; Available online: http://www.counties.org/images/public /Advocacy/ag_natres/AEP_Global_Climate_Change_June_29_Final\%5B1\%5D.pdf (accessed on 17 May 2010).

73. Walters, D. It's Jerry Brown vs. GOP again. The Sacramento Bee, 25 July 2007.

74. Natural Resources Defense Council, v. Reclamation Board of the Resources Agency of the State of California. Case No. 06 CS 01228, Superior Court of California, County of Sacramento; State of California: Sacramento, CA, USA, 2007.

75. NRDC suit marks shift in legal strategy for NEPA climate reviews. Carbon Control News, 2 April 2007, Volume 1, No. 12.

76. Dispute over GHG reviews rage despite recent California agreement. Carbon Control News, 15 October 2007, Volume 1, No. 40.

77. Kings County Farm Bureau v. City of Hanford. 221 Cal. App. 3d 692, 720 (Cal. App. 5th Dist. 1990); State of California: Sacramento, CA, USA, 1990.

78. Cal. Pub. Resources Code $\$ 21083(b)(2)$; West's Annotated California Codes: Eagan, MN, USA, 2007.

79. Cal. Admin. Code \$15130; West's Annotated California Codes: Eagan, MN, USA, 2007.

80. Ebbetts Pass Forest Watch v. California Department of Forestry \& Fire Protection. 123 Cal. App. 4th 1331, 1350 (Cal. App. 3d Dist. 2006) (citing, Kleppe v. Sierra Club, 427 U.S. 390, 412 (1976) (Determining the area to be used to assess cumulative impact is based on the specific facts of a project. For instance, biological assessments may vary according to species. In addition, "The determination...requires the weighing of a number of relevant factors, including the extent of the interrelationship among proposed actions and practical considerations of feasibility. Resolving these issues requires a high level of technical expertise and is properly left to the informed discretion of the responsible federal agencies.").

81. Los Angeles Unified School Dist. v. City of Los Angeles. 58 Cal App 4th 1019 (Cal App 2d Dist. 1997); State of California: Sacramento, CA, USA, 1997.

82. Citizens to Preserve the Ojai v. County of Ventura. 176 Cal. App. $3 d 421$ (Cal. App. 2d Dist. 1985); State of California: Sacramento, CA, USA, 1997.

83. Laurel Heights Improvement Assn. v. Regents of University of California. 47 Cal. 3d 376, 404-405 (Cal. 1988); State of California: Sacramento, CA, USA, 1997.

84. McMurry, R.I. Considering Climate Change in the CEQA Process. In Proceedings of the 23rd Annual ALI-ABA Land Use Institute Conference, San Francisco, CA, USA, 16-18 August 2007.

85. A.G.'s Settlement with Refinery May Set Precedent for How to Handle Industrial Expansion. Calif. Environ. Insid. 2007, 21, 6-15.

86. The People of the State of California, ex rel. Attorney General Edmund G. Brown Jr. v. County of San Bernardino. Case No. CIVSS 0700329, Order Regarding Settlement; United States Supreme Court: Washington, DC, USA, 28 August 2007; Available online: http://ag.ca.gov/ cms_pdfs/press/2007-08-21_San_Bernardino_settlement_agreement.pdf (accessed on 17 May 2010). 
87. California Reaches Landmark Global Warming Settlement on County's Growth Plan. Mealey's Poll. Liab. Rep. 2007, 20, 20-21.

88. Smart-growth bill to cut greenhouse gases clears hurdle in California. Carbon Control News, 16 July 2007, Volume 1, No. 27. (One source is quoted in the article as saying “...I do not see a scientific basis for determining how much mitigation is needed to reduce the impact to a less-than-significant level").

89. Letter from Edmund, G. Brown, Jr. to Janet Stern Principal Planner, Pleasanton Community Development Department, 13 January 2009, p. 6; Available online: http://ag.ca.gov/ globalwarming/pdf/comments_Pleasanton_GP_FEIR.pdf. (accessed on 17 May 2010).

90. A subsequent letter, from the Attorney General to Ms. Stern criticized the Final Environment Impact Report's conclusion that the greenhouse gas emissions from projected new construction "will be less significant" as patently unreasonable, 8 May 2009; Available online: http://ag.ca.gov/globalwarming/pdf/comments_Pleasanton_GP_FEIR.pdf (accessed on 17 May 2010).

91. Shigley, P. Marin County General Plan Embraces Sustainability; Calif. Plan. Dev. Rep. 2008, 23, No. 1.

92. Marin Countywide Plan; Marin County Community Development Agency: Marin County, CA, USA, 6 November 2007; Available online: http://www.co.marin.ca.us/depts/cd/main/fm/cwp docs/CWP_CD2.pdf (accessed on 17 May 2010).

93. Bank of America; UC Berkeley School of Law Center for Law, Energy \& the Environment; UCLA School of Law Environmental Law Center \& Emmett Center of Climate Change and the Environment; Office of the California Attorney General. Removing the Roadblocks: How to Make Sustainable Development Happen Now; Joint Policy Paper; UC Berkeley School of Law Center for Law, Energy \& the Environment: Berkeley, CA, USA, August 2009.

94. For an elegant articulation of this conclusion in the context of geographical theories of the interaction of space, scale and regulation see Osofsky, H.M. Scaling "Local": The Implications of Greenhouse Gas Regulations in San Bernardino County. Mich. J. Int. Law 2009, 30, 689-705.

(C) 2010 by the authors; licensee MDPI, Basel, Switzerland. This article is an Open Access article distributed under the terms and conditions of the Creative Commons Attribution license (http://creativecommons.org/licenses/by/3.0/). 